\section{Bring Back the Joy in Neuroradiology}

(DD.M. Yousem, DK.P. Yousem, and DK.A. Skarupski

n School of Medicine leadership forums, affinity group meetings of the Association of American Medical Colleges, and at the American Medical Association, everyone is talking about "resilience," "burnout," and "attrition." "-4 Medical practitioners struggle with the demands of serving their patients, finding meaning in their work in the face of increased emphasis on revenue generation and regulatory demands, and maintaining some semblance of a home life. In our field of neuroradiology, recognized by the readership of the American Journal of Neuroradiology as the best profession ever, we too have experienced anxiety when we hear about the future changes in health care that dampen our positive attitudes.

However, if we focus only on how to build resilience, prevent burnout, handle disappointments, or prevent attrition, we have already lost the battle. What we want instead is to be delighted to be at work! Fun! Pleasure! In this short editorial, we hope to provide you with some tips on returning joy to neuroradiology.

\section{Mission Centric}

Believing in the principles of the mission of your work is the first step to joyfulness in that work. If you believe in the vision and values of your practice and the worthiness of committing energy to its success, you will have a sense of purpose that enables a sense of satisfaction. ${ }^{1,5}$ We advocate strongly for a thoughtful intermittent full staff review of the mission statement of the practice and a commitment to dedicating necessary resources to achieving the goals in that statement. When you believe in your work, you are happy performing it. ${ }^{2,5}$

\section{Empowerment}

Physicians are often, by virtue of their profession, considered leaders in their community. Part of enhancing job satisfaction resides in finding the individual niches in which all members of the team are empowered and eager to lead, grow, and excel. ${ }^{6}$ Centralization of power under 1 Director/CEO/President/ Chairman with autocratic governance should be weighed against providing colleagues responsibility and encouragement to determine that part of the practice where they have jurisdiction/sovereignty/growth to be creative. ${ }^{2}$ That may mean considering assigning directors of spine imaging, brain imaging, head and neck imaging, fellowship training, residency training, medical student training, outpatient clinics, hospital services, and so forth, within neuroradiology. When people do what they love, their work excels, and data show that physicians spending at least $20 \%$ of their professional effort doing the work they find most meaningful are at much lower risk of burnout. ${ }^{3}$ Give people an opportunity to shine and then shine the spotlight on their good work, which leads to. .

http://dx.doi.org/10.3174/ajnr.A5392

\section{Gratitude}

People want to be appreciated. One of the best ways to foster a happy workplace is to have an attitude of gratitude, in which finding someone doing something right is the norm. ${ }^{7}$ Having people feel comfortable complimenting each other in an open fashion takes practice to sound sincere and not forced. Consider "Thankful Thursdays," when people are encouraged to acknowledge the exceptionally positive interactions in their work life in a public way. Build an atmosphere of beneficence.

\section{Mindfulness}

While we all must be planful about addressing the challenges of the future, mindfulness training brings one back to present conditions. When mindful, one focuses awareness on the present moment, channeling the inner harmony of body and mind, yet being available to others. Being able to engage fully in the moment (and put away our social media/electronic distracting devices) allows one to set the mind at peace and connect fully with patients, colleagues, and loved ones. ${ }^{8-10}$ Setting aside several minutes each day for refocusing, be it meditation or introspection or self-reflective exercises, has long-term joy-inspiring consequences.

\section{Play}

Nothing has inspired greater joy in our workplace than the playfulness we bring to our jobs in neuroradiology. Whether it is dressing up in kooky outfits for Halloween or showering faculty with candy/games/shaving cream/jokes, cultivating an atmosphere of light-heartedness is good. Having leadership dress up in self-deprecating costumes for Halloween or Santa outfits for the winter holidays are examples of transforming the dreariness of the mundane into a super-special delightful day. The suspense about how the boss will be dressed this year in September and October lends a cheerfulness to the workplace that far exceeds the cost of an Ironman costume. Daily 15- to 20-minute competitions for a month devoted to Sudoku/finding the missing words/puzzlers/scavenger hunts also can lighten the mood during the heavy-volume periods at work. A 5-minute dance party elevates the mood and energizes an often-sluggish midafternoon (the introverts here get to pick the music, clap on the side, and take the embarrassing videos to post to social media). Share joy.

\section{Decorations}

Why do people ride around sundry neighborhoods during the winter/Christmas festival times? Why have some Jewish families adopted Hanukkah bushes? Why are the Kwanza lights and Diwali fireworks so popular? For whatever reason, seeing decorations and holiday cheer (on the walls of your office/workplace/ building and so forth) in a tasteful and diversity-respectful manner brings joy to the workplace. ${ }^{11}$ After an initial investment, being able to pull out wall decorations for the New Year, Valentine's Day, St Patrick's Day, Springtime, Memorial Day, Independence Day, Thanksgiving, Halloween, Winterfest, and Elvis Presley commemorations has a dramatic impact on those coming to 
work. You create a party atmosphere based on the environment. Working here is fun.

\section{Celebrations}

Festivities that acknowledge group and individual successes or milestones help to create a positive mental outlook at work. Have you installed that new magnet in the department? Party! Junior faculty member got her first RO1? Celebrate at work! Instead of going to the corner bar for champagne, let the workplace become associated with the successes and the happy place where those successes are recognized. Combine the partying with acknowledgment of the diversity within your work group by selecting ethnic food for the revelry with nation-specific music selections, and you can multiply the good will that such celebrations inspire. Take the opportunity to acknowledge success and have the work environment be the place for celebrations. ${ }^{4,12}$

\section{Group Exercise and Nutrition}

In healthy people, being joyful is easier. Exercise, movement releases, and healthy meals and snacks at work will inspire better spirit and more energy. ${ }^{13}$ In 1 such initiative, we spent 20 minutes a day doing staff-led dance instruction with the goal of being the best dancing division at the winter holiday departmental party. Doing line dances led by experienced talented members of the team not only showed what people are capable of outside of work but also allowed moving in a fun fashion that built enthusiasm throughout the day...before and after the lessons. Some team members even felt an improved self-image because they were finally, with practice, able to move more rhythmically on the dance floor (yes, we mean you Dave Yousem!). Make sure you are offering heart-healthy whole foods and plant-based treats at these breaks.

These are just some ideas that can be implemented at a low cost of time, energy, and finances yet yield great gains for building happiness at work. Each of these categories of interventions can be discussed more fully with the leadership team, but often the initiatives are best implemented from rank and file ideas that are part of an explicit program to bring the joy back to the workplace.
Disclosures: David M. Yousem—UNRELATED: Expert Testimony: self, medicolegal expert witness; Payment for Lectures Including Service on Speakers Bureaus: American College of Radiology Education Center; Royalties: Elsevier for 5 books.

\section{REFERENCES}

1. Shanafelt TD, Noseworthy JH. Executive leadership and physician well-being: nine organizational strategies to promote engagement and reduce burnout. Mayo Clin Proc 2017;92:129-46 CrossRef Medline

2. Shanafelt TD, Gorringe G, Menaker R, et al. Impact of organizational leadership on physician burnout and satisfaction. Mayo Clin Proc 2015;90:432-40 CrossRef Medline

3. Shanafelt TD, West CP, Sloan JA, et al. Career fit and burnout among academic faculty. Arch Intern Med 2009;169:990-95 CrossRef Medline

4. Sklar DP. Fostering student, resident, and faculty wellness to produce healthy doctors and a healthy population. Acad Med 2016;9: 1185-88 CrossRef Medline

5. Michel JB, Sangha DM, Erwin JP 3rd. Burnout among cardiologists. Am J Cardiol 2017;119:938-40 CrossRef Medline

6. Swensen S, Kabcenell A, Shanafelt T. Physician-organization collaboration reduces physician burnout and promotes engagement: the Mayo Clinic experience. J Healthc Manag 2016;61:105-27 Medline

7. Kelly JD 4th. Your best life: breaking the cycle: the power of gratitude. Orthop Relat Res 2016;474:2594-97 CrossRef Medline

8. Beach MC, Roter D, Korthuis PT, et al. A multicenter study of physician mindfulness and health care quality. Ann Fam Med 2013;11: 421-28 CrossRef Medline

9. Goyal M, Singh S, Sibinga EM, et al. Meditation programs for psychological stress and well-being: a systematic review and metaanalysis. JAMA Intern Med 2014;174:357-68 CrossRef Medline

10. Gotink RA, Chu P, Busschbach JJ, et al. Standardised mindfulnessbased interventions in healthcare: an overview of systematic reviews and meta-analyses of RCTs. PLoS One 2015;10:e0124344 CrossRef Medline

11. Smith L. 9 Things Science Says Your Home Needs If You Want to Be Happy. Good Housekeeping. November 7, 2016. http://www. goodhousekeeping.com/home/decorating-ideas/g3164/scientificreasons-household-items-make-you-happy/. Accessed July 7, 2017

12. Hu YY, Fix ML, Hevelone ND, et al. Physicians' needs in coping with emotional stressors: the case for peer support. Arch Surg 2012;147: 212-17 CrossRef Medline

13. McClafferty $\mathrm{H}$, Brown OW. Physician health and wellness. Pediatrics 2014;134:830-35 CrossRef Medline 